\title{
THE ACT OF STATE DOCTRINE: REVIVED BUT SUSPENDED
}

\author{
Roland A. PaUl $\dagger$
}

\section{A Brief History}

In 1892, as was the custom in those days in Latin America, revolution raged in Venezuela. The civil war went well for the revolutionaries; their general, Jose Manuel Hernandez, occupied Ciudad Bolivar on August 13, 1892. American citizens even then left their homeland occasionally. One such American, George F. Underhill, fortuitously was operating the waterworks in Ciudad Bolivar just when it fell to General Hernandez. The General, not surprisingly, required Underhill to continue operating those facilities for the benefit of the revolutionary forces.

A few years later, ${ }^{1}$ after returning to the United States, Underhill brought a lawsuit against Hernandez ${ }^{2}$ for false imprisonment and assault and battery in connection with the events at Ciudad Bolivar. Ultimately the United States Supreme Court, in affirming judgment for the defendant, declared that:

Every sovereign State is bound to respect the independence of every other sovereign State, and the courts of one country will not sit in judgment on the acts of the government of another done within its own territory. Redress of grievances by reason of such acts must be obtained through the means open to be availed of by sovereign powers as between themselves. ${ }^{3}$

Although the holding was laden with references to the proper conduct of war, Underhill $v$. Hernandez has generally been recognized as the genesis of the act of state doctrine, the subject of the present Article. ${ }^{4}$

The doctrine was applied by the Court again in 1909. In American Banana Co. v. United Fruit Co., ${ }^{5}$ Mr. Justice Holmes ex-

$\dagger$ A.B. 1958, Yale University; LL.B. 1961, Harvard University. Member, New York Bar.

1 In the meantime, the United States had recognized the revolutionary government espoused by Hernandez as the legitimate government of Venezuela.

2 Underhill v. Hernandez, 65 Fed. 577 (2d Cir. 1895), aff'd, 168 U.S. 250 (1897).

3168 U.S. at 252.

4 Earlier intimations of the concept can be found in Hudson v. Guestier, 8 U.S. (4 Cranch) 293 (1808); The Schooner Exchange v. M'Faddon, 11 U.S. (7 Cranch) 116, 136 (1812); and The Santissima Trinidad, 20 U.S. (7 Wheat.) 283, 336 (1822), all relating to the seizure of vessels.

5213 U.S. 347 (1909). 
plained and justified the act of state doctrine in terms of his well-known positivist theory of law. ${ }^{6}$ The Court refused to consider a charge that the defendant had conspired with the Costa Rican Government to deprive the plaintiff of its plantation and railroad. In 1918, in the related cases of Oetjen v. Central Leather Co. ${ }^{7}$ and Ricaud v. American Metal Co., ${ }^{8}$ involving property which had turned up in the United States after being taken by General Carranza's commanders during the Mexican Civil War of 1913, the Supreme Court accepted the Mexican seizures as legally valid and binding. In addition to the retroactive effect of this country's de jure recognition of General Carranza's Government, the Court relied on the Underhill proposition that the redress of grievances at the hands of a foreign sovereign acting within its own territory must be had, if at all, through diplomatic channels or the courts of that sovereign, not through the courts of this country. ${ }^{\circ}$ The Court insisted in Oetjen that review of sovereign acts by the courts of another country "would very certainly 'imperil the amicable relations between governments and vex the peace of nations." "10 It added that even a review of the taking through application of the rules of international law was not available in American courts.

Although the doctrine was referred to in passing in Shapleigh $v$. Mier, ${ }^{11}$ United States $v$. Belmont, ${ }^{12}$ and United States $v$. Pink, ${ }^{13}$ and followed frequently in the lower courts, ${ }^{14}$ it did not reappear as central and controlling in any decision of the Supreme Court until last year in the case of Banco Nacional de Cuba v. Sabbatino. ${ }^{15}$

$6[I] t$ is a contradiction in terms to say that within its jurisdiction it is unlawful to persuade a sovereign power to bring about a result that it declares by its conduct to be desirable and proper. It does not, and foreign courts cannot, admit that the influences were improper or the results bad. It makes the persuasion lawful by its own act. The very meaning of sovereignty is that the decree of the sovereign makes law.

Id. at 358.

7246 U.S. 297 (1918).

8246 U.S. 304 (1918).

9 The Supreme Court did not lable the "act of state" doctrine as such until Banco Nacional de Cuba v. Sabbatino, 376 U.S. 398 (1964).

10246 U.S. at 304.

11299 U.S. 468 (1937).

12301 U.S. 324 (1937).

13315 U.S. 203, 233 (1942).

14 See, e.g., Pons v. Republic of Cuba, 294 F.2d 925 (D.C. Cir. 1961), cert. denied, 368 U.S. 960 (1962) ; Bernstein v. Van Hyeghen Freres Societe Anonyme, 163 F.2d 246 (2d Cir.), cert. denied, 332 U.S. 772 (1947); United States ex rel. Von Heymann v. Watkins, 159 F.2d 650 (2d Cir. 1947); Banco de Espana v. Federal Reserve Bank, 114 F.2d 438 (2d Cir. 1940); The Claveresk, 264 Fed. 276 (2d Cir. 1920); Hewitt v. Speyer, 250 Fed. 367 (2d Cir. 1918); Eastern States Petroleum Co. v. Asiatic Petroleum Corp., 28 F. Supp. 279 (S.D.N.Y 1939) ; Holzer v. Deutsche Reichsbahn-Gesellschaft, 277 N.Y. 474, 14 N.E.2d 798 (1938); Dougherty v. Equitable Life Assur. Soc'y of the United States, 266 N.Y. 71, 193 N.E. 897 (1934); M. Salimoff \& Co. v. Standard Oil Co., 262 N.Y. 220, 186 N.E. 679 (1933). 15376 U.S. 398 (1964). 
The doctrine, however, was given signal treatment in Bernstein v. Van Heyghen Freres, S.A., ${ }^{16}$ involving Nazi confiscation of Jewish property. There the Second Circuit adhered to the act of state rule until the State Department, responding to an invitation from Judge Hand, ${ }^{17}$ informed the plaintiff's attorneys that it was State Department policy "to relieve American courts from any restraint upon the exercise of their jurisdiction to pass upon the validity of the acts of Nazi officials." 18 Thereupon, the Second Circuit, per curiam, rescinded its earlier mandate to the district court and allowed that court to pass upon the validity of the Nazi decree of confiscation.

The pre-Sabbatino "act of state" doctrine is open to dual interpretation. Some courts appear to say that the existence of local "law"-i.e., a legislative or executive act-in a sovereign state precludes the existence of any separate body of rules through which a court in another country may judge the validity of the local "law" in question. This seems to have been Mr. Justice Holmes' view of the matter in American Banana Co. v. United Fruit Co. However, the language in several other cases suggests that there is no juridical barrier to review by a domestic court of the act of another sovereign, but that in the interests of this country's foreign affairs, courts should not involve themselves in such questions. United States $v$. Pink, ${ }^{19}$ for example, gave such an interpretation to Oetjen and Underhill. Despite such ambiguity in its underpinnings, the act of state doctrine in its application had. run a rather consistent course, with Bernstein the only significant exception. A reasonably tidy stage was set for Sabbatino.

\section{The Sabbatino Case and the Amendment}

In retaliation against the United States' reduction of that portion of its sugar quota allotted to Cuba, Castro's Government, on August 6, 1960 , nationalized the Cuban property of twenty-six American companies, of which one was the sugar producer Compania Azucarera Vertientes-Camaguey de Cuba (CAV).$^{20}$ Meanwhile, a shipment of $\mathrm{CAV}$ sugar was being loaded aboard a vessel at the Cuban port of

16163 F.2d 246 (2d Cir.), cert. denied, 332 U.S. 772 (1947), accord, Bernstein v. N. V. Nederiandsche-Amerikaansche Stoomvaart-Maatschappij, 210 F.2d 375 (2d Cir. 1954), anending per curiam 173 F.2d 71 (2d Cir. 1949).

17163 F.2d at 251.

18 Dep't State Press Release No. 296, April 27, 1949, 20 Dep't State Butl. 592 (1949) ; see 210 F.2d at 376.

19315 U.S. 203, 233 (1942).

20 Although CAV had been incorporated in Cuba, over $90 \%$ of its stockholders were United States' nationals. 
Jucaro under contracts of sale between CAV and the American sugar broker, Farr, Whitlock \& Co. Only after Farr-Whitlock had renegotiated these same contracts with the Cuban Government was the sugar permitted to leave for its destination, Casablanca. Thereupon, the Government of Cuba, through its financial representative, Banco Nacional de Cuba, sent the bills of lading to New York for negotiation. By rapid legal maneuvers, Farr-Whitlock managed to obtain the bills of lading from Banco Nacional's representative in New York, negotiate them, obtain payment for the shipment of sugar, and then pay over the proceeds to Peter Sabbatino, who had been appointed as receiver for CAV.

Banco Nacional brought suit in the Southern District of New York against Farr-Whitlock for conversion of the bills of lading and their proceeds, and against Sabbatino for an injunction to prevent him from exercising jurisdiction over the sums paid to him. The district court dismissed the complaint, concluding that the act of state doctrine was inapplicable in the presence of a violation of international law. It found three distinct bases for such a violation: (1) the Cuban decree was not reasonably related to a public purpose, but rather was issued as an act of retaliation against this country; (2) the decree was discriminatory; and (3) it failed to provide adequate compensation. ${ }^{21}$ The Second Circuit affirmed, holding that certain messages from the State Department to counsel in this and a similar pending case made the act of state doctrine inapplicable, and that the Cuban decree did violate international law because it combined inadequate compensation with a retaliatory purpose and a discriminatory result. ${ }^{22}$

The Supreme Court reversed, and it remanded the case to the district court with the anticipated result that the funds formerly held in the receivership would be paid to the Alien Property Custodian, the present holder of all Cuban assets in the United States. The Court's opinion resolved a number of significant questions: (1) despite her break in diplomatic relations with the United States, Cuba could maintain an action in the courts of the United States; (2) the act of state doctrine, although not required either by the provisions of the Constitution or by the principles of international law, was a part of our federal common law binding on state and federal courts alike; (3) the proper execution of the foreign policy of this country by the political branches, as well as progress toward the rule of law among nations, was best served by precluding the judicial branch from examining "the validity of a taking of property within its own territory by a foreign 
sovereign government, extant and recognized by this country at the time of suit, in the absence of a treaty or other unambiguous agreement regarding controlling legal principles, even if the complaint alleges that the taking violates customary international law"; ${ }^{23}$ and (4) a foreign sovereign could invoke the act of state doctrine even as a partyplaintiff and thereby obtain affirmative relief. ${ }^{24}$

The Court itself certainly would not have considered its decision in Sabbatino an instance of judicial abstention or abdication. Rather, the majority quoted from the Ricaud opinion as to the nature of the act of state doctrine: "To accept a ruling authority and to decide accordingly is not a surrender or abandonment of jurisdiction but is an exercise of it." 25 It is true that in Sabbatino the Court did adjudicate the controversy between the parties and did apply a law, the Cuban decree. That the result was in favor of the plaintiff demonstrates that, in one sense of the term, there was no abstention in Sabbatino.

Nonetheless, in another sense, the application of the act of state doctrine here, as in the earlier act of state cases, could still be considered a form of abstention. ${ }^{26}$ In the ordinary choice of law situation, whether between the laws of two territorial jurisdictions, such as two states, or between overlapping jurisdictions, such as state and federal authority, the court is free to inquire into any aspect of the relation between either contending body of law and the subject matter of the lawsuit; and where two bodies of law happen to apply to the same subject, to reconcile the two according to their respective weight and substance. But under the act of state doctrine, the court makes the choice of law depend upon foreign policy considerations which prohibit it from even verbalizing the precepts of the rejected alternative. The questions of relationship and priority are never reached. The act of state doctrine is similar in this respect to the now limited doctrine of "political questions." $2 \pi$

The story of Sabbatino does not end, however, with the decision rendered by the Supreme Court. On October 2, 1964, Congress pro-

23376 U.S. at 428.

24 The Court also ruled that the refusal of American courts to effectuate the penal and revenue laws of another State or Country did not extend to a fully executed decree of expropriation, and that it was not proper for American courts to pass upon the validity of a foreign sovereign's act under the law of that foreign state.

25246 U.S. at 309 , quoted in 376 U.S. at 418.

${ }^{26}$ See, e.g., Henkin, The Foreign Affairs Power of the Federal Courts: Sabbatino, 64 Colum. L. Rev. 805, 822 (1964). Compare Restatement, Foreign Relations LAW OF THE UNITED STATES \$ 75(2) (Proposed Official Draft 1962); Jessup, Has the Supreme Court Abdicated One of Its Functions?, 40 AM. J. IsT'L L. 168 (1946); Lyons, The Conclusiveness of the 'Suggestion' and Certificate of the American State Department, 24 BRTT. YB. INT'L L. 116, 146-47 (1947).

27 See Baker v. Carr, 369 U.S. 186, 208-37 (1962). 
vided that no American court should, because of the act of state doctrine, fail to apply international law in any case commencing before January 1, 1966, in which a confiscation or other taking by a foreign state occurring after January 1, 1959, was involved, unless: (1) the foreign act was not contrary to international law; (2) the claimant's right was based upon a 180-day or less irrevocable letter of credit issued prior to the confiscation; or (3) the executive branch specifically invoked the act of state doctrine by filing with the court a suggestion to that effect. And to make its intent abundantly clear, Congress told the courts directly in the legislation that its view of international law included prompt, adequate, and effective compensation. ${ }^{28}$

Thus, for a brief period, American courts will be allowed to pass judgment in accordance with international law (as interpreted by Congress) upon certain acts committed by foreign states. It may well turn out that the only cases in which the amendment will ever be applied are Banco Nacional de Cuba v. Farr, ${ }^{29}$ and the other pending cases involving $\mathrm{Cuba}$ on which adjudication had been postponed awaiting the outcome of the Sabbatino case. However, the Senate-House conference report states that the expiration date for the amendment was accepted on the understanding that the matter would be fully reviewed during the next Congress to determine the need for permanent legislation in this area. ${ }^{30}$

28 Foreign Assistance Act of 1964, §301(d) (4), 78 Stat. 1013:

Notwithstanding any other provision of law, no court in the United States shall decline on the ground of the federal act of state doctrine to make a determination on the merits giving effect to the principles of international law in a case in which a claim of title or other right is asserted by any party including a foreign state (or a party claiming through such state) based upon (or traced through) a confiscation or other taking after January 1, 1959, by an act of that state in violation of the principles of international law, including the principles of compensation and the other standards set out in this subsection: Provided, That this subparagraph shall not be applicable (1) in any case in which an act of a foreign state is not contrary to international law or with respect to a claim of title or other right acquired pursuant to an irrevocable letter of credit of not more than 180 days duration issued in good faith prior to the time of the confiscation or other taking, or (2) in any case with respect to which the President determines that application of the act of state doctrine is required in that particular case by the foreign policy interests of the United States and a suggestion to this effect is filed on his behalf in that case with the court, or (3) in any case in which the proceedings are commenced after January 1, 1966.

29 This being the current name of the Sabbatino case on remand in the Southern District of New York.

30 H.R. REP. No. 1925, 88th Cong., 2d Sess. 16 (1964). In its dash toward adjournment the House did not have sufficient time in its 1964 session to make an adequate appraisal of the amendment originally proposed by Senator Hickenlooper for reversing the Sabbatino opinion. The amendment as finally enacted was a hastilydrawn compromise. See ibid.; H.R. 11380, 88th Cong., 2d Sess. \$301(f) (1964) (S. Amend. 39, Sept. 24, 1964). See also S. REp. No. 1188, pt. 1, 88th Cong., 2d Sess. 24 (1964). 


\section{A Rationale: The Reguirements of Foreign Relations}

The major theme of the Court's opinion in Sabbatino was the insistence that the executive branch not be hampered in its handling of foreign policy by a judicial decision as to the validity of an expropriation. The Court saw dire consequences in any such decision: (1) a holding against the validity of a foreign act might insult the sovereign committing the act or a third sovereign similarly situated and thus render less favorable a possible diplomatic settlement of the claims held by all American citizens; or (2) a judicial decision in favor of the validity of the decree or a judicial pronouncement that international law was unclear on the point was likely to undercut the State Department's contentions with respect to the expropriating decree and thus render more difficult efforts at a general settlement. Furthermore, the Court felt that the interests of diplomacy as well as the proper role of the courts demanded application of the act of state doctrine without a requirement of its prior affirmative invocation by the executive branch. $^{31}$ We proceed to examine these contentions.

\section{A. Effects of Judicial Invalidation of a Foreign Act}

Even if an American court should rule a foreign act to be in violation of international law, the offense to the sensitivities of the expropriating country in most cases pales in comparison with the other insults which the United States might, and often does, hurl at the expropriator. The Cuban situation is illustrative. Already the State Department had denounced the Cuban seizures as violations of international law. ${ }^{32}$ The President had placed an embargo on all United States trade with Cuba. ${ }^{33}$ The Deputy Attorney General of the United States had asserted in open court that the seizures were in violation of international law. The Bay of Pigs invasion in 1961 coupled with the 1962 missile crisis removed more than a little sting from a possible judicial decision contrary to the Castro regime.

There are, to be sure, cases of expropriation not evoking the extreme animosity of the Cuban-American vendetta. To provide for these the act of state doctrine could be modified to permit a court to

31 The Court felt constrained to justify its application of the act of state doctrine at some length-it did not merely rely upon earlier precedent. Unpersuasive efforts have been made to distinguish Sabbatino from the cases of Underhill, Ricand, and Oetjen. See, e.g., 376 U.S. at $442-44$ n.2 (White, J., dissenting); 1 OpPENHET, INTERNATIONAI LAW § 115ab, at $268 \mathrm{n} .2$ (8th ed. Lauterpacht 1955). (1960).

32 Dep't State Press Release No. 397, July 16, 1960, 45 Dep't State Buld. 171

23 Proclamation No. 3447, Feb. 6, 1962, 27 Fed. Reg. 1085 (1962). 
review the validity of a foreign decree only when there is present at the time of judgment any one of certain objective indicia of cool relations between the United States and the other country. These could include the severance of diplomatic relations, the freezing of assets in this country under section 5(b) of the Trading With the Enemy Act, ${ }^{34}$ the embargo of trade between the two countries, ${ }^{35}$ and the suspension of foreign aid under the Hickenlooper Amendment to the Foreign Assistance Act. ${ }^{36}$

In view of the State Department's present acceptance of this amendment, ${ }^{37}$ the policy reasons are not clear for avoiding a judicial determination contrary to a particular expropriation. The possibility of such a judicial decision would offer the State Department yet another argument to make to a foreign government considering expropriation, while the effect of such a judicial decision, once made, would usually be no harsher than action taken by the United States Government pursuant to the Hickenlooper Amendment.

Provided that courts were also to give great weight to specific requests from the State Department for judicial abstentions, embarrassment to this country's foreign policy under such a modified act of state doctrine would be most unlikely. Indeed, the frequent refusal of American courts to recognize the validity of foreign confiscations in the past, to the extent that those confiscations purported to affect titles to property or other legal rights beyond the territorial borders of the

3455 Stat. 839 (1941), 50A U.S.C. §5(b) (1958).

35 See, e.g., Foreign Assistance Act of 1961, $\$ 620$ (a), 75 Stat. 444 (1961), as amended, 22 U.S.C. \$2370(a) (Supp. V, 1964).

3876 Stat. 260 (1962), as amended, 22 U.S.C. $\$ 2370$ (e) (1) (Supp. V, 1964), as amended, 22 U.S.C.A. \$2370(e) (1) (Supp. 1964) :

The President shall suspend assistance to the government of any country to which assistance is provided under this chapter or any other act when the government of such country or any government agency or subdivision within such country on or after January 1,1962-

(A) has nationalized or expropriated or seized ownership or control of property owned by any United States citizen or by any corporation, partnership, or association not less than 50 per centum beneficially owned by United States citizens . . .

and such country, government agency or government subdivision fails within a reasonable time . . . to take appropriate steps, which may include arbitration, to discharge its obligations under international law toward such citizens or entity, including speedy compensation for such property in convertible foreign exchange, equivalent to the full value thereof, as required by international law ...

The United States suspended aid to Ceylon under this statute on February 8, 1963. 48 Dep't State BuLl. 328-29 (1963).

37 See Hearings on H.R. 10327, 10536, 10720, 12259 and 12260 Before the Subcommittee on Inter-American Affairs of the House Committee on Foreign Affairs, 88th Cong., 2d Sess. 145-46 (1964) (comments of State Department Acting Legal Adviser Meeker); 110 CoNG. REc. 18944 (daily ed. Aug. 14, 1964) (remarks of Senator Hickenlooper). 
expropriating state, does not appear to have jeopardized our relations abroad. ${ }^{38}$

As to the State Department's efforts at settling all private American claims arising out of a particular governmental taking, again there is serious question whether an unfavorable judicial determination would have any significant effect on the State Department's task of negotiating a settlement, especially since the State Department would have the right, at least at any time before final judgment, to seek judicial abstention in a particular case. ${ }^{39}$ Furthermore, claims negotiation, although important work, is not of the same significance as those matters of foreign policy which bear directly upon the national security of this country, those matters to which extreme deference must be paid. Foreign affairs are not all of the same magnitude. The Sabbatino Court failed to make this clear.

The claims negotiating work of the State Department has not been insignificant. In 1917 Mexico nationalized all its land and water resources including those owned by Americans, thus creating claims on the part of American citizens in the amount of 350 million dollars. In 1941 these claims were settled through a commitment by Mexico to pay 40 million dollars in annual installments. In 1938 Mexico seized all alien-owned oil properties. An American claim of 260 million dollars was settled four years later for approximately 24 million dollars plus three percent interest. ${ }^{40}$

Settlements for the expropriations in Eastern Europe which followed World War II were of a similar order. American claims against

38 See, e.g., Plesch v. Banque Nationale de la Republique d'Haiti, 273 App. Div. 224, 77 N.Y.S.2d 43, aff'd per curiam, 298 N.Y. 573, 81 N.E.2d 106 (1948); Second Russian Ins. Co. v. Miller, 268 U.S. 552 (1925) (dictum); Vladikavkazsky Ry. v. New York Trust Co., 263 N.Y. 369, 189 N.E. 456 (1934).

39 The overall amount of American claims in the negotiated settlement would, of course, be reduced by the amount of the private litigan's recovery in court. Likewise the funds recovered by the successful private litigant would not be included in the amount of frozen assets of the expropriating country held in the United States. Cf. Stephen v. Zivnostenska Banka Nat'l Corp., 15 App. Div. 2d 111, 118-19, 222 N.Y.S.2d 128, 136 (1961) (dictum). If, on the other hand, the private litigant, as a result of the application of the act of state doctrine, had not been successful in court, and the amount in dispute had become part of the frozen assets of the expropriator, and these frozen assets were distributed among all claimants under a general settlement, the result under American notions of private property would be tantamount to the taking of one man's property to reimburse partially each of the other persons similarly injured. This might have a superficial appeal as an equitable sharing of the loss, but it seems contrary to basic concepts of private property in this country. Furthermore, in one man's hands the funds recovered may appear substantial, but if distributed among all claimants may well be de minimis. Cf. Timberg, Expropriation Measitres and State Trading, 1961 American Soc'y International L. ProceEdings $113,120$.

40 Dawson \& Weston, "Prompt, Adequate, and Effective": A Universal Standard of Compensation?, 30 FordHAM L. REv. 727, 740-41 (1962). By waiting until 1947 the British were apparently able to strike a better bargain for their petroleum interests. For claims about equivalent to those held by United States citizens, the United Kingdom was able to recover $\$ 130$ million for its citizens. Id. at 741 . 
Rumania totaling 84,729,291 dollars were settled in March 1960 for $24,526,370$ dollars. However, all but 2.5 million dollars of this settlement was paid out of frozen assets held in this country, for which Rumania's consent was hardly necessary. ${ }^{41}$ Similarly, an agreement was reached with Bulgaria in 1963 by which claims totaling 4,600,000 dollars were settled by the application of $3,143,398$ dollars in frozen assets and the further Bulgarian contribution of 400,000 dollars. ${ }^{42}$ Against Yugoslavia, American citizens held claims totaling an estimated 150 million dollars. The United States in 1948 returned gold to Yugoslavia which had been sent to the United States for safekeeping during the war. Of a total of $46,800,000$ dollars in gold involved, the United States was authorized to liquidate 17 million dollars in settlement of American claims against Yugoslavia. ${ }^{43}$ Finaily, in July 1960 Poland agreed to pay to the United States some 40 million dollars over a period of twenty years and to negotiate directly with American citizens holding Polish Government bonds amounting to 45 million dollars. In return the United States released 1 million dollars of Polish assets in the United States. It should be added that during the period 1958-1962 the United States was lending Poland 61 million dollars and selling to her farm produce at low prices totaling 293 million dollars. ${ }^{44}$ And shortly after the agreement on American claims, this country accorded Poland most-favored-nation tariff treatment. ${ }^{45}$

Two examples from Latin America demonstrate approximately the same degree of success. In 1952 Bolivia seized three foreign-owned tin mines. In 1960 she agreed to pay full compensation out of tin revenues, but only after the United States promised to buy 15,000 tons of tin at world market prices from the nationalized companies and to double its Point Four aid. When tin revenues fell below eighty cents per pound on the world market, Bolivia was relieved of her commitment. $^{46}$ In 1962, when one of the Brazilian states took from a subsidiary of International Telephone and Telegraph Corporation

41 Christenson, The United States-Rumanian Claims Settlement Agreement of March 30, 1960, 55 AM. J. INT'L L. 617, 621-22 (1961); see Agreement With Rumania, March 30, 1960, [1960] 11 U.S.T. \& O.I.A. 317, T.I.A.S. No. 4451.

42 Dep't State Press Release No. 354, July 2, 1963, 49 Dep't State Bull. 138 (1963). In fact under domestic United States law some of the claims had already been paid before the international settlement was reached. Ibid.; see 69 Stat. 562 (1955), 22 U.S.C. $\$ \S 1631-41 q$ (1958).

43 Dawson \& Weston, supra note 40, at 743-44; see Agreement With Yugoslavia, July 19, 1948, 62 Stat. 2658 (1948), T.I.A.S. No. 1803.

44 Dawson \& Weston, supra note 40 , at 745 ; see Agreement With Poland, July 16,1960 , [1960] 11 U.S.T. \& O.I.A. 1953, T.I.A.S. No. 4545.

45 See Tyler, Department Supports Discretionary Authority for President on Trade with Poland and Yugoslavia, 48 Dep't State Bull. 947, 948, 949 (1963).

46 Dawson \& Weston, supra note 40, at 745 n.97. 
holdings valued at 6-8 million dollars, the Brazilian Government agreed to grant the company a loan equal to 80 percent of the value of the property seized. IT\&T, however, was committed to invest this amount in one of its manufacturing subsidiaries in Brazil. ${ }^{47}$

Mr. Justice Harlan pointed out for the Sabbatino Court that countries expropriate for many reasons, "political and ideological as well as economic." 48 Countries settle claims arising out of expropriations for just as many reasons. Clearly, the settlement with Yugoslavia in 1948, the settlements with Rumania and Poland in 1960, and even the Litvinov Agreement with the Soviet Union in $1933^{49}$ stemmed mainly from each country's view of its own national interest and little from its concept as to the requirements of international law. In such a context a judicial decision either for or against a particular seizure should have slight or no effect upon the situation. At the very least it can be said that the risk of jeopardizing some future diplomatic settlement is slight enough to be outweighed by the obligation of the court to work justice in the case before it and the desirability of fostering a rule of law among nations.

A judicial decision adverse to an expropriation would be no more harmful in other regards. The Court feared that it could embarrass our relations with a third country involved in similar expropriations. Here, as elsewhere in the opinion, the Court's observation suggests its acceptance of a rule of decision which subordinates the development of international law to the Court's conception of the national interest, ${ }^{50}$ for by hypothesis the third country would have been as guilty of violating international law as the expropriating nation involved in the immediate lawsuit. The Court's position as applied to third countries similarly situated is no stronger than it is with respect to our relations with the country committing the immediate expropriation. Again, it would seem that requiring the State Department affirmatively to seek judicial abstention would be sufficient protection for the national interest in this respect.

The Court maintained that judicial relief was only limited relief, whereas a diplomatic settlement was general relief. ${ }^{51}$ But that depends upon one's point of view. Judicial decisions can work complete justice as to the subject matter before the court, which may or may not represent a substantial recovery to the injured litigant. Claims nego-

47 See N.Y. Times, April 13, 1962, p. 1, col. 1.

48376 U.S. at 435 .

49 Dep't of State Publication No. 528, 1933, [1933] 2 Foreign ReI. U.S. 805-14.

50 At the end of the section of the opinion now under discussion, the Court, however, asserts without explanation that its opinion will contribute to the growth of international law as well as to the national interest. 376 U.S. at 437.

51 See p. 697 supra. 
tiations, on the other hand, often extend over many years and, if successful at all, result in reimbursement only after the property expropriated has been written off as a total loss. Such reimbursement is often a mere fraction of the value of the property seized. To call such relief "general" is misleading to say the least.

Finally, in regard to decisions adverse to an expropriation, the Court discounted any deterrent effect such decisions might have on future expropriations. The Court's attitude here appears somewhat inconsistent with its attribution of a strong "insulting" effect to such judgments. It is rather hard for the Court to have it both ways: judicial decisions frustrate settlements but in no way deter expropriations. It is more reasonable to assume that judicial decisions adverse to expropriations are likely either to have little effect on both settlements and expropriations or are likely both to interfere with possible settlements and to deter future expropriations. Under either alternative judicial abstention is inadvisable. If judgments have no significant effect on settlements or expropriations, the Court might as well render justice in the case before it and, in so doing, make a contribution to the rule of law among nations. If judgments are likely to affect both settlements and expropriations, deterring an expropriation is preferable to permitting settlement after expropriation, since deterrence is complete justice (i.e., the owners' property is saved in toto) whereas settlements work only partial justice-often a very small part. Of course it is unclear in the abstract how much property will be saved from would-be expropriators and how much a settlement will be diminished as a result of judicial decisions. The only reasonable conclusion is that any expectation would involve such unresolved conjecture that the Court could not fairly have based its decision on the assumption that, if the Court abstained from judgments adverse to expropriations, more property would more likely be recovered through settlements than saved from expropriation. ${ }^{.2}$

\section{B. Effects of Judicial Affirmation of a Foreign Act}

A holding that the Cuban expropriation was not inconsistent with international law would certainly not have been an insult to Cuba

52 Although, in the body of the opinion, the Court adopted the position that deterrence was unlikely, in two footnotes it gave some support to the contrary proposition. 376 U.S. at 431 n. 36,433 n.38. In these footnotes the Court stated that adverse judicial decisions might disincline persons from bringing expropriated property into this country, but would not deter expropriations if other markets could be found for the goods. But what about those products for which other markets cannot be found? The United States is the predominant market for many items. A rule of international law against certain types of expropriations, if followed by the United States and a number of other countries, could effectively close a large share of the world market to expropriators of many types of products. Surely this would have a deterrent effect in at least some cases. 
and, therefore, would not have affected in any significant way those matters of high foreign policy which directly bear upon the security of this country. ${ }^{53}$ The Court believed, however, that such a holding might undercut the State Department's efforts to reach a claims settlement. ${ }^{54}$ But such an undercutting was not inevitable-a skillful opinion might have avoided it by pointing out that even though the rules of international law did not require prompt, adequate, and effective compensation for American citizens whose property had been taken, adequate compensation for any taking of private property was not only the well-known policy of this country, but also a concept of justice held by many persons and many nations throughout the world. If a particular country wants our friendship, it will respect our principles and policies to the extent that it is able; and if it does not care for our friendship, at least in the present international situation, it will probably not pay us regardless of the rules of international law. As indicated above, ${ }^{55}$ the settlement of claims today is based upon what each country believes to be prudent in its own self-interest, a concept little, if at all, connected with what anyone asserts to be the precepts of international law. Perhaps most important, a rule of judicial decision that failure to pay "prompt, adequate and effective" compensation is no violation of international law such as to create a right of recovery (or cognizable defense) in court is not necessarily inconsistent with another rule of international law which would recognize an obligation on the part of an expropriating country to accommodate the victims of expropriation to some extent through diplomatic channels at a future date. ${ }^{58}$

Another point to consider is this: a decision of a court, in Sabbatino the Highest Court, should not be based on the necessity of protecting another agency in its exposition of erroneous legal theories. If what the State Department asserts to be the law is not what our courts believe it to be, should the State Department be allowed to continue in error? This was another of those places in the Sabbatino opinion where the Court seems to subordinate the development of law

53 In fact, it would seem that the effect on foreign policy from such a decision would hardly have been different from the effect of the actual decision in Sabbatino.

54 The Court believed, perhaps rightly, that it not only had to avoid a direct refutation of the State Department's position, but also had to avoid even casting doubt upon that position by pronouncing the rules of international law to be cloudy on the relevant point. 376 U.S. at 433 . But earlier in the Sabbatino opinion itself the Court took the position that the rules of international law regarding expropriations were far from clear. 376 U.S. at $428-30$. Thus, the Court committed in fact the very error it dreaded so much in the abstract.

65 See text accompanying notes 48-49 supra.

56 Even Communist countries appear to recognize some obligation in the direction of compensation for victims of expropriation, although the relief is neither prompt nor adequate. See text accompanying notes $41-46,73-74$ supra. 
to a so-called national interest. If the State Department's past interpretation of international law was mistaken, possibly that Department in the future would be more effective, and certainly more candid, if it decided to emphasize the fact that confiscation can lead to the loss of investment capital from abroad or decided to base its future arguments upon a concept of friendship between nations, mutual respect for each other's policies, and a code of morality not yet embodied in current concepts of international law.

Congress has now reversed the Court's refusal to limit application of the act of state doctrine to cases where the State Department affirmatively invokes it. The Court's variant result rests on a number of unconvincing propositions. First, the majority was reluctant to reject the Government's argument in court that such an arrangement would "work serious inroads on the maximum effectiveness of United States diplomacy." 57 However, no one has cited a single historical instance in which the State Department could not have come forward in a particular litigation to seek a result favorable to a foreign power. ${ }^{58}$ As to the Court's belief that the timing required of the State Department might be inopportune for affirmative invocation, the Court here, as elsewhere, appears to have been overly solicitous of the role of a State Department whose operations do not in fact require such protection.

The Court even gave great weight to the possibility that adverse domestic consequences might ensue from the State Department's taking an official position. As Justice White pointed out in his dissent, however, the domestic position of the State Department, that is, its political image, is an inadequate basis upon which to ground a rule of decision. ${ }^{59}$ Finally, the Court doubted "whether the examination of validity by the judiciary should depend on an educated guess by the Executive as to probable result ...." A0 Although all of the Court's other grounds for not requiring affirmative invocation were intended to protect the State Department, this final argument was directed toward benefiting the courts. But the Court here was advancing no weightier argument than that no loaf was better than half, i.e., that the role of the judiciary was better served by complete abdication in favor of the executive (no examination of validity in any case) than by a partial deference to the executive.

57376 U.S. at 436.

58 The State Department has many times "suggested" the sovereign immunity of foreign states in lawsuits against such states. See Republic of Mexico v. Hoffman, 324 U.S. 30 (1945); United States v. Melekh, 190 F. Supp. 67 (S.D.N.Y. 1960). Compare the case of the three Kenya students charged with felonious assault. N.Y. Times, Aug. 20, 1964, p. 10, cols. 7-8.

59 See 376 U.S. at $468-69$ (White, J., dissenting).

$60 I d$. at 436. 
The opinion resolved all doubts in favor of avoiding even the most tenuous possibility of embarrassment to the State Department. The Supreme Court certainly has not shown such deference in other cases touching upon matters of national security. ${ }^{61}$ A rule of decision might have been drafted which would have more carefully balanced the proper roles of the judiciary and the executive. ${ }^{62}$

\section{Another Rationale: The Posture of}

\section{INTERNATIONAL LAW}

The Sabbatino decision rests on double rationales. The first concerns the needs of the State Department. The second, not entirely separate from the first, involves the present nature of international law with respect to expropriations. The Court felt that judicial determinations regarding confiscation were inappropriate in view of (1) the wide division in world opinion as to the limits on a state's authority to expropriate the property of aliens, ${ }^{63}$ and (2) the close relationship between confiscation and national ideology among the various nations.

\section{A. International Consensus Regarding Expropriations}

International law has been described as the body of rules, derived from custom, treaties, and general principles of law, which have been accepted either expressly or tacitly by the overwhelming majority of nations. ${ }^{64}$ If this is a satisfactory definition, then the Court's claim of

61 See, e.g., Greene v. McElroy, 360 U.S. 474 (1959).

62 The possibility of lawsuits over property in this country by citizens of one foreign country against another foreign country which has expropriated their property should not be overlooked. This type of litigation could prove most ticklish for United States foreign relations. If both countries involved are friends of the United States, it may be awkward for the State Department to show a preference by recommending any particular result to the court. For such cases the advantages of requiring the presence of objective indicia of animosity between this country and the expropriating one are clear. If no indicia of animosity are present, the court would apply the act of state doctrine, granting judgment in favor of the expropriator. The court would not have to discuss the relationship between the expropriation and international law.

If, however, indicia of animosity are present, the court would have to proceed to the merits of the case. A decision against the confiscation would not upset American foreign policy in such a situation. A decision in favor of the expropriation, on the other hand, could ruffle feelings in the homeland of the persons whose property has been seized. There is at least no direct insult to that country, however, since it is not the official act of that country which is being contested before the court. Furthermore it would probably be inequitable to allow foreigners to recover in situations in which our courts would not allow recovery to American citizens. Throughout our history American courts have entertained lawsuits involving aliens and concerning all sorts of litigable issues-our foreign policy has not suffered noticeably as a result.

63 It should be apparent that the greater the degree of codification or consensus concerning a particular area of international law, the more appropriate it is for the judiciary to render decisions regarding it, since the courts can then focus on the application of an agreed principle to circumstances of fact rather than on the sensitive task of establishing a principle not inconsistent with the national interest or with international justice.

376 U.S. at 428.

64 See 1 OppeNHen,, op. cit. supra note $31, \S \S 5,11,19$. 
a lack of consensus regarding expropriations was equivalent to alleging an absence of international law prescribing bounds to what a state might properly do in this field. However, the Court was quick to deny such an inference. In a footnote it declared: "We do not, of course, mean to say that there is no international standard in this area; we conclude only that the matter is not meet for adjudication by domestic tribunals." ${ }^{65}$ It is regrettable that the Court did not choose to explain the meaning of this footnote more fully, since on its face it appears inconsistent with the text of the opinion.

In support of its conclusion, the majority compared the positions taken by Western governments, Western commentators, and certain international tribunals, in contrast with the avowed policies of Communist countries and of certain newly independent and underdeveloped countries. This comparison demonstrates a lack of agreement on the necessity of paying prompt, adequate, and effective compensation to the victims of expropriations. Although many countries, including some Communist states, have paid lip service to the concept of compensation, an obligation to pay full or even substantially equivalent compensation is not recognized in many parts of the world. ${ }^{66}$ Accordingly, the Supreme Court correctly declined to recognize a general rule on this point.

It is also true, as the Sabbatino majority mentioned, that many underdeveloped nations consider the traditional postulates of international law as reflecting only the interests of the wealthy, capitalexporting states at the expense of the nations not so fortunate. ${ }^{67}$ But this simply means that to some extent the old rules are no longer properly a part of international law, and that new rules must be devised which more fairly reconcile the just interests of all nations, regardless of their economic, cultural, social, and ideological conditions-rules which have the consent, albeit tacit, of the overwhelming majority of nations. ${ }^{68}$

There were available, however, principles of law relevant to the case at hand upon which a general consensus did exist. These relate

65376 U.S. at 429 n.26.

68 In fact, Abram Chayes, the former Legal Adviser to the State Department, stated that it was the position of the United States only to demand compensation "that is reasonably adequate and reasonably prompt." Chayes, The Lawyer and the Alliance for Progress, 47 DeP'T STATE BULL. 192, 195 (1962). See also 1 OPPENHEIM, op. cit. supra note $31, \$ 155 d$, at 352 . See generally Banco Nacional de Cuba v. Sabbatino, 307 F.2d 845, 862-64 (2d Cir. 1962).

67 See, e.g., Roy, Is the Law of Responsibility of States for Injuries to Aliens a Part of Universal International Law?, 55 AM. J. INT'L L. 863 (1961); 1 U.N. INTERNATIONAL LAW COMM'N, 1957 YEARBOOK 155, 158 (A/CN. 4/SER.'A/1957) (U.N. Pub. Sales No. 1957-V.5, Vol. 1).

68 See Dawson \& Weston, supra note 40, at 757. 
to the issue of discrimination by Cuba against aliens of a particular nationality. Support can readily be found for the proposition that a taking which discriminates against a class of people, such as aliens of a particular nationality, is contrary to international law. ${ }^{69}$ Unlike the case against compensation, exponents of the theory that discrimination is permitted by international authority are extremely rare. ${ }^{70}$ The authorities cited by the Court urge no such proposition. ${ }^{\mathbf{7 1}}$ In fact, Bystricky, professor of private international law at the Charles University of Prague, Czechoslovakia, cited by the Court, actually concludes that "international law only proscribes discrimination and interdiction, but in no way prescribes the payment of compensation for nationalized property." 72

A review of Communist nationalizations supports Bystricky. In their property-takings Czechoslovakia, Poland, and Yugoslavia seized property without regard to the nationality of the owners. Each provided some form of compensation except for owners of German (or, in the case of Czechoslovakia, Hungarian) nationality-a distinction based on nationality certainly, but one which was an integral part of the general settling of accounts between belligerents at the conclusion of hostilities. International law as yet does not proscribe the confiscation of enemy property nor the exacting of reparations. ${ }^{73}$ In her nationalization Hungary repudiated all pre-August 1, 1946, contractual

${ }^{69}$ See Anglo-Iranian Oil Co. v. S.U.P.O.R. Co., [1955] Int'1 L. Rep. 23,42 (No. 22) (1954); The Oscar Chinn Case, P.C.I.J. ser. A/B, No. 63 (1934); Standard Oil Tankers Cases, 22 Am. J. InT't L. 404, 419-20 (1928); Restatensent, ForeigN Relatrons Law of the UnIted States $\$ 170$ \& illustration 2 (Proposed Official Draft 1962) ; Netherlands Note to Indonesia, Dec. 18, 1959, 54 AM. J. INT'L L. 484, 485-87 (1960) ; United States Note to Rumania, 19 Dep'T State Burl. 408 (1948); American Branch of the International Law Assoctation, Proceedings and Committee Reports 1959-1960, at 31 (1960); Forghex, Natronalization: A Study in the Protection of Alien Property in INTERnational Law 47 (1957); FrIEDMAaN, Expropriation in INTERnatronal Law 189-93 (1963); van Hecke, Confiscation, Expropriation, and the Conflict of Lazes, 4 InTERNational L.Q. 345 (1951); Verdross, Die Nätionalisierung Niederlandischer Unternehmungen in Indonesien Im Lichte des Völkerrechts, 6 NEDERLANDS TIJDSCHRIFT VOOR INTERNATIONAL RECHT 278 (1959); 6 NeDERLaNdS TIJDSCHRIFT VoOR INTERNational RECHT 260, 269 (1959) (remarks of Professor Rolin); Affaire des Biens Britanniques Au Maroc Espagnol, 2 U.N. Rep. Int'l Arb. Awards 615, 647 (1925) (Britain/Spain).

70 See Fatouros, Governarent Guarantees to Foreign Investors $249-51$ (1962).

71 Fleming, States, Contracts, and Progress 62-63 (1960); Bystricky, Notes on Certain International Legal Problems Relating to Socialist Nationalisation, in International Association of Democratic Lawyers, Proceedings of the Comsartssion on Private International Law, IVtr Cong. 15 (1956); 1 U.N. INTERNATIONAL LAW CoMM'N, op. cit. supra note 67, at 155, 158 (remarks of Mr. Padilla Nervo of Mexico and Mr. Pal of India); Anand, Role of the "New" Asian-African" Countries in the Present International Legal Order, 56 AM. J. INT'L L. 383 (1962); Doman, Postwar Nationalization of Foreign Property in Europe, 48 CoLUM L. Rev. $1125,1127,1143-58$ (1948) ; Roy, supra note 67.

72 Bystricky, supra note 71, at 24.

73 See, e.g., Joint Resolution Terminating War, §5, 42 Stat. 106 (1921) ; 2 OpPENHEIM, INTERNATIONAL LAW \$102 (7th ed. Lauterpacht 1952). 
obligations owing to Hungarian citizens, but respected similar claims owed to foreigners-not a discrimination against foreigners, but a preference for them. Hungary, in accordance with her peace treaty, also exempted from nationalization the property of the Allied Governments and their nationals. Rumania made no distinction in its nationalization except to exempt property of a foreign state entitled to such property under Rumania's treaty of peace or her reparation commitment-again a distinction associated with the conclusion of war. Bulgaria seized property of all persons regardless of nationality except German assets in Bulgaria given to the Soviet Union by the Allied Control Council for Germany. She provided a form of compensation except for wartime enemies and persons "incriminated in activity to restore fascism" in Bulgaria. With the possible exception of this very last distinction, the persons in each category precluded from compensation under the Bulgarian nationalization were so treated because of activities connected with World War II. Furthermore, to the extent that the compensation provided by these Eastern European countries proved to be illusory, there was in practical effect no discrimination at all. ${ }^{74}$

Elsewhere in the world expropriations have generally not been directed toward the nationals of a particular country as such, despite cursory appearance in certain cases. Mexico in 1938 seized only alienowned oil properties, but several foreign countries were involved. When Iran nationalized its oil industry in 1951, only British interests were involved, but no one else held similar property. In the same way the Egyptian nationalization of the Universal Suez Maritime Canal Company involved all foreign interests. And in 1964 the Congo appropriated to its sole ownership all concession-granting rights within its territory which were formerly owned jointly by the Congolese Government and private Belgian interests. ${ }^{75}$ But there was little evidence in any of these situations that the expropriating sovereign

74 See Doman, supra note 71, at 1143-57.

Bystricky makes the following comment with respect to socialist nationalizations:

It follows clearly that socialist nationalisation can be regarded neither as confiscation nor as expropriation. Confiscation has a punitive element in it, while nationalisation is in no sense a punitive measure. It is true that at the beginning of the socialist revolution the deprivation of property had sometimes, in certain individual cases, a repressive character, but these are extreme cases. The property in question was in every case nationalised. The great body of nationalisation measures cannot, consequently be judged according to a certain number of extreme cases. Socialist nationalisation has in its essence nothing in common with sanctions. Expropriation deals only with a comparatively small group of people, and a comparatively unimportant number of objects pass into State ownership. Here again the quantitative and qualitative difference is pronounced.

Bystricky, supra note 71, at 18.

75 N.Y. Times, Dec. 5, 1964, p. 1, col. 3. 
was singling out any particular nationality for treatment different from that which would have been accorded any other nationality which was or might have been similarly situated; and, in all of the foregoing cases except the first, there is no indication that even equivalent interests owned by nationals of the expropriating country, had there been any, would not have received similar treatment. ${ }^{76}$ The nearest precedent in recent history for Castro's seizures was the Indonesian seizure of Dutch property in 1958 with the stipulation that no compensation would be paid so long as the Netherlands continued to hold West New Guinea. ${ }^{77}$

Whether the Cuban seizures of only American property constituted discrimination would depend on whether it was reasonable and equitable under the circumstances for Cuba to respond in this fashion against the United States' reduction of Cuba's sugar quota. I believe that it was not. Both the American and the Cuban acts involved economic coercion against the other country. However, it can hardly be considered a violation of any recognized standard of law for one country to decide to change its pattern of trade for any reason satisfactory to itself. Therefore, we have a prima facie violation of international law, so to speak, on Cuba's part following a valid exercise of sovereign authority on the part of the United States. The purported justification for the Cuban violation of international law would thus fail.

\section{B. Confiscation and Ideology}

The Court also believed that confiscation so "touches . . . the practical and ideological goals of the various members of the community of nations" as to render it unsuitable for adjudication by American courts. This inference involves essentially the same considerations which we have examined previously, for it was based upon either the assumption that judicial determination would interfere with State Department efforts in the same field or the assumption that courts lack the skills necessary to resolve questions involving international political sensitivities. I have attempted to demonstrate in the preceding section that a limited judicial role would not be likely to hamper any significant foreign policy of this country. It may be added here that an adjudication by an American court over a limited and specific res would not bind any subsequent general claims settlement reached by the State Department and the foreign government, except as to the particular property before the court.

76 Fatouros, op. cit. supra note 70, at 250-51.

77 See Dawson \& Weston, "Prompt, Adequate and Effective": A Universal Standard of Compensation?, 30 FordHaM L. Rev. 727 (1962). 
Judicial competence in this area should not be underestimated: the courts certainly are in a better position than other agencies to elaborate general, impartial rules which could form a body of international law. ${ }^{78}$ Furthermore, the subject of confiscations is of no greater sensitivity than espionage, ${ }^{79}$ nationality, ${ }^{80}$ diplomatic immunity, ${ }^{81}$ political crimes, ${ }^{82}$ freedom of the seas, ${ }^{83}$ and conduct of war. ${ }^{84}$ American courts do not fear these areas.

The problem is overstated when the field is termed politically sensitive. It should be asked only whether adjudication in this field, even limited by all reasonable safeguards, is likely to create political difficulties. If domestic courts must run from all areas that touch upon national sensitivities, this path to an international order under law is forever foreclosed, precisely because it is problems in these very fields with which international law must ultimately deal, and deal effectively, if its true significance as an alternative to trial by battle is ever to be realized. And until the day of effective international adjudication, what path is open to us other than through domestic cotrits ? 85

78 It should not be necessary at this date in our legal development to argue in detail that courts have certain capabilities, perhaps not shared in the same degree by the executive branches of government, to apply general legal rules, whether international or national, in specific controversies for the protection of private rights and the promotion of basic community objectives.

Brief for the Executive Committee of the American Branch of the International Law Association as Amicus Curiae, p. 15, Banco Nacional de Cuba v. Sabbatino, 376 U.S. 398 (1964).

79 See United States v. Soblen, 301 F.2d 236 (2d Cir.), cert. denied, 370 U.S. 944 (1962); United States v. Abel, 258 F.2d 485 (2d Cir. 1958), aff'd, 362 U.S. 217 (1960).

80 See Schneider v. Rusk, 377 U.S. 163 (1964) ; Perkins v. Elg, 307 U.S. 325 (1939).

81 See Bergman v. De Sieyes, 170 F.2d 360 (2d Cir. 1948); United States ex rel. Casanova v. Fitzpatrick, 214 F. Supp. 425 (S.D.N.Y. 1963); Únited States v. Rosal, 191 F. Supp. 663 (S.D.N.Y. 1960).

82 See 18 U.S.C. \$3184 (1958) ; Karadzole v. Artukovic, 247 F.2d 198 (9th Cir. 1957), vacated and remanded per curiam, 355 U.S. 393 (1958); Ivancevic v. Artukovic, 211 F.2d 565, 566 n.3 (9th Cir.), cert. denied, 348 U.S. 818 (1954).

83 See The Paquete Habana, 175 U.S. 677 (1900).

84 See In re Yamashita, 327 U.S. 1 (1946).

85 The remedies available outside the municipal courts to an individual injured by a foreign State through a violation of international law are limited at best. Should the individual succeed in having his claim espoused by the State of which he is a national (which he ordinarily has no legal right to demand), there is no international tribunal of general and mandatory jurisdiction to which his State may present the claim in the event that diplomatic representations prove ineffectual. Moreover, international tribunals such as the International Court of Justice ordinarily have no procedures by which they can enforce their decisions.

Committee on International Law, Association of the Bar of the City of New York, Report, A Reconsideration of the Act of State Doctrine in United States COURTS 1-2 (1959).

Related to the foregoing propositions, the Court in Sabbatino took the position that world conditions were now too fluid for the "patchwork approach" of formulating 


\section{The Foreign Assistance Amendment}

To a certain extent the congressional amendment to section 620(e) of the Foreign Assistance Act of 1961 is simply a reversal of Banco Nacional de Cubav. Sabbatino. As the Senate Foreign Relations Committee explained:

The effect of the amendment is to achieve a reversal of presumptions. Under the Sabbatino decision, the courts would presume that any adjudication as to the lawfulness under international law of the act of a foreign state would embarrass the conduct of foreign policy unless the President says it would not. Under the amendment, the Court would presume that it may proceed with an adjudication on the merits unless the President states officially that such an adjudication in the particular case would embarrass the conduct of foreign policy. ${ }^{86}$

In several respects, however, the amendment has other significance. First, Congress apparently accepted the Court's proposition that the act of state doctrine was not constitutionally prescribed, ${ }^{87}$ and further agreed with the Court in considering the act of state doctrine a matter for federal, not state disposition. ${ }^{88}$ The amendment speaks of "no court in the United States" instead of "no United States court" or "no court of the United States," an obvious attempt to reach state as well as federal courts.

Perhaps more significantly, the amendment points to the conclusion that within our federal system international law will be an aspect of federal law instead of state law. Happily, Congress did not have to achieve its result, as the Supreme Court apparently thought it had to, by resorting to a broad notion of federal common law. At least for a short period, international law with respect to confiscations can now be elaborated by the federal courts (and state courts under federal aegis) on the basis of a direct mandate from Congress. The approach of Clearfield Trust Co. v. United States ${ }^{89}$ and Textile Workers

a body of international law and that decisions of American courts would likely appear biased elsewhere in the world. But have not conditions appeared too fluid to the existing generation for centuries, and are they not likely to appear so to all future generations? Whether an opinion appears to be biased depends, at least in part, upon the position taken by the judge. Is it inevitable that our courts will take the parochial view, especially if ultimate review of their decisions will lie with the United States Supreme Court?

86 S. Rep. No. 1188, 88th Cong., 2d Sess. 24 (1964).

87 See 376 U.S. at 423.

88 See id. at 425; Henkin, The Foreign Affairs Power of the Federal Courts: Sabbatino, 64 Coluar. L. REv. 805 (1964).

80318 U.S. 363 (1943). 
Union v. Lincoln Mills, ${ }^{90}$ for expanding the body of federal court-made law, has apparently arrived, albeit temporarily, in yet another area of jurisprudence. $^{91}$ The amendment does not conclusively determine which law-state or federal - is to be applied to aspects of international relations other than seizures of property. However, ultimate favor for federalizing this area is likely portended by this legislation.

Another interesting aspect of the amendment is the extent to which it prescribes substantive rules under the rubric of international law. By reading together subsections (e) (1) and (e) (2) of the statute as now amended, we discover Congress saying that international law requires "speedy compensation for such [expropriated] property in convertible foreign exchange, equivalent to the full value thereof." 82 Under the Constitution, Congress may prescribe the laws of the United States, and American courts must follow such dictates. But does Congress have the authority to prescribe the rules of general international law? As that term is used within the American constitutional system, the answer would be yes; ${ }^{93}$ but beyond our shores the answer obviously must be no. Legislative enactments, like the decisions of domestic courts and the writings of legal seers, are only evidence of that general customary international law which is applicable to all nations. Thus American courts must follow what Congress has announced to be international law, not because it is international law in the purest sense of the term, but because it is the law of the United States.

The amendment provides that it shall not apply in any case where the foreign act is not contrary to international law or where title or other rights are acquired pursuant to a letter of credit issued in good faith before the confiscation. The conference report on this point merely states that the conferees "amended the Senate language to pinpoint its precise effect." ${ }^{94}$ Perhaps the purpose of this conference change was to preserve to American bankers their traditional force majeure defense in private contract law against liability on such letters of credit. However, the first part of this proviso-the language about acts not contrary to international law-can also apply to litigation like that in Sabbatino where title to the confiscated property itself is the subject matter of the dispute. Two cases can be imagined: first, where a foreign seizure is not contrary to international law (as that term

90353 U.S. 448 (1957).

91 See generally Friendly, In Praise of Erie-and of the New Federal Common Law, 39 N.Y.U.L. REv. 383 (1964).

82 Foreign Assistance Act of 1964, §301(e)(1)-(2), 78 Stat. 1013.

93 See U.S. Const., art. I, § 8, cl. 10.

94 H.R. REP. No. 1925, 88th Cong., 2d Sess. 16 (1964). 
has now been defined by Congress), but may be unenforceable here for some other reason, such as its being contrary to the "public policy" of the forum; and second, where the foreign act is valid and enforceable under international law, and no other rule of decision renders it unenforceable here. In both cases the proviso apparently requires the court to render judgment in favor of the foreign state (or one claiming rights from that state) on the basis of the act of state doctrine instead of rendering a judgment which would articulate principles of international law or public policy. However, such judicial opinions could hardly conceal the implicit conclusions of the court that the act was valid under international law. Therefore, there seems little reason, at least in the second situation, to require a court to intone the act of state doctrine.

Finally, let us suppose that a court actually does promulgate some international law during the grace period provided by the amendment, but that Congress then fails to renew the amendment at its expiration. Which precedent should subsequent courts follow, Sabbatino or the decision reached during the period of the amendment? It would seem that Sabbatino and its rule would be resurrected, and the substantive decision, being in a way only the interpretation of a statute, would pass away with its generating statute. 